\title{
Methamphetamine-induced behavioral sensitization in mice: alterations in $\mu$-opioid receptor
}

\author{
Chi-Tso Chiu, Tangeng Ma \& Ing K. Ho* \\ Department of Pharmacology and Toxicology, University of Mississippi Medical Center, 2500 North State \\ Street, Jackson, MS, 39216, USA
}

Received 11 May 2006; accepted 21 June 2006

(C) 2006 National Science Council, Taipei

Key words: $\mu$-opioid receptor, behavioral sensitization, constitutive activity, DAMGO, G protein, methamphetamine, neuroadaptations

\begin{abstract}
Summary
We had previously demonstrated that opioid receptors contribute to the induction and expression of behavioral sensitization induced by repeated daily injection with $2.5 \mathrm{mg} / \mathrm{kg}$ of methamphetamine for 7 days. Using the same regimen, the present study investigated the alterations in $\mu$-opioid receptor during the induction (on days 2, 5, and 8) and expression (on days 11 and 21) periods of behavioral sensitization. Radioligand binding revealed that the maximal binding of $\mu$-opioid receptor was not changed on days 2 and 5, but down-regulated on day 8. After cessation of drug treatment, the maximal binding of $\mu$-opioid receptor gradually and time-dependently returned to normal level on day 11 and up-regulated on day 21 . In contrast, no changes in $\delta$ - and $\kappa$-opioid receptors were detectable on any given day examined. The potency of DAMGO for $\left[{ }^{35} \mathrm{~S}\right]-\mathrm{GTP} \gamma \mathrm{S}$ coupling was enhanced on days $2,5,11$, and 21 . Moreover, $1 \mu \mathrm{M}$ of naltrexone or $\beta$-chlornaltrexamine significantly suppressed the basal $\left[{ }^{35} \mathrm{~S}\right]-\mathrm{GTP} \gamma \mathrm{S}$ coupling on days 2 , 11 , and 21. These findings indicate enhanced responsiveness and elevated constitutive activity of $\mu$-opioid receptor. In summary, our data clearly demonstrate that alterations in $\mu$-opioid receptor are involved in and may contribute to the sensitization to locomotor stimulating effect of methamphetamine.
\end{abstract}

Abbreviations: ANOVA - analysis of variance; AMPH - amphetamine; $\beta$-CNA - $\beta$-chlornaltrexamine; DAMGO - [D- $\mathrm{Ala}^{2}, \mathrm{~N}$-Me-Phe $\mathrm{C}^{4} \mathrm{Gly}^{5}$-ol]-enkephalin; DPDPE - [D-Pen ${ }^{2,5}$-enkephalin; GDP - guanosine $5^{\prime}$-diphosphate; $\left[{ }^{35} \mathrm{~S}\right]-\mathrm{GTP} \gamma \mathrm{S}-$ guanosine $5^{\prime}-O-\left(3-\left[{ }^{35} \mathrm{~S}\right]\right.$-thio $)$ triphosphate; METH - methamphetamine;

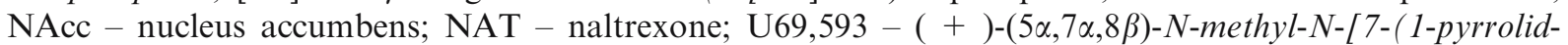
inyl)-1-oxaspiro[4.5]dec-8-yl]-benzeneacetamide; VTA - ventral tegmental area

\section{Introduction}

Continued use of psychostimulants such as amphetamine (AMPH), methamphetamine $(\mathrm{METH})$, and cocaine is typically associated with the development of tolerance. However, repeated intermittent exposure to these drugs was found to produce "reverse tolerance" known as behavioral

*To whom correspondence should be addressed. Fax +1-601984-1637, E-mail: iho@pharmacology.umsmed.edu sensitization, which is characterized by progressive and enduring augmentation of the behavioral effects in response to subsequent exposure to the same dose of the drug $[1,2]$. Behavioral sensitization has been used as an animal model for studying the development of craving in addicts and psychosis that arises from repeated exposure to psychostimulants $[2,3]$.

METH is a synthetic drug and chemically related to AMPH but has a higher potential for 
abuse. The behavioral activating effects of AMPH are thought to depend primarily on its ability to increase dopamine release in the terminal regions of the mesolimbic dopamine system [4]. The ventral tegmental area (VTA) is the somatodendritic region of the mesolimbic dopamine neurons, whose nerve terminals project primarily to the nucleus accumbens (NAcc), an important structure for mediating spontaneous and pharmacologically stimulated locomotor activity [5]. The mesolimbic dopamine system has been implicated in the rewarding effects of drugs of abuse [6]. It is clear that neuroadaptations in the VTA and NAcc are critical for the induction and expression of behavioral sensitization to psychostimulants, respectively [7, 8]. In addition to anatomical differences, the processes of induction and expression of behavioral sensitization are also temporally distinct. An abundance of neuroadaptive phenomena observed during the establishment and expression of behavioral sensitization was occurring in a time-dependent fashion [9], suggesting different neuronal mechanisms were involved.

Topographic overlaps between opioid and dopamine neurons were found in the VTA, substantia nigra, striatum, and limbic areas, suggesting that there are interactions between these two systems [10]. Our previous study in mice showed that, pretreatment with naltrexone (NAT), a nonselective opioid receptor antagonist, attenuated the induction and expression of METH-induced behavioral sensitization [11]. When administered prior to daily METH treatment, the inhibitory effect of NAT on the induction of behavioral sensitization appeared to vanish after a longer period of abstinence. Moreover, when administered prior to METH challenge, the inhibitory effect of NAT on the expression of behavioral sensitization was found to be more effective after a longer period of abstinence. These differential effects of NAT indicated potential alterations in opioid receptors after repeated METH treatment, which might be time-dependent and definitive for expression of behavioral sensitization.

Endogenous opioids have been suggested to play a key role in mediating the rewarding effects of psychostimulants. It is well accepted that $\kappa$-opioid receptors play a role in opposing the behavioral consequences induced by repeated psychostimulant administration [12]. In addition, although agonists of $\delta$ - and $\mu$-opioid receptors exhibit rewarding property, it has been found that $\mu$ - but not $\delta$-opioid receptors play a major role in modulating mesolimbic dopamine system [13-15]. Pharmacological evidence reveals that mesolimbic dopaminergic activity can be controlled by $\gamma$-aminobutyric acid (GABA), a major inhibitory afferent in this brain region [16]. In the VTA, activation of $\mu$-opioid receptors located possibly on both GABA afferent and interneurons is known to hyperpolarize these GABA-containing neurons and decrease GABA release [17, 18]. Therefore, the neuronal activity of mesolimbic dopamine neurons is also indirectly regulated by $\mu$-opioid receptors in the VTA through GABA. Accordingly, activation of $\mu$-opioid receptors led to increase in dopamine neuronal activity and subsequent dopamine release in the NAcc [18, 19], whereas blockade of the receptor resulted in a significant decrease in baseline and AMPHinduced dopamine levels in the NAcc [15, 19].

Acute administration with AMPH or METH is known to increase the expression of opioid peptide mRNA and neurotransmission of endorphin in the brain [20, 21], and mesolimbic structures such as VTA and NAcc receive $\beta$-endorphin containing fibers [22]. It was found that the GABA contents of the midbrain were decreased $1 \mathrm{~h}$ after a single administration of METH [23], suggesting the activation of $\mu$-opioid receptors in the VTA. Therefore, repeated METH treatment during the induction period of behavioral sensitization may cause repeated or persistent activation of $\mu$-opioid receptor. Moreover, activation of $\mu$-opioid receptors in the VTA is known to mediate food intake behavior [24]. It was found that not only the feeding $[24,25]$ but also the dopamine releasing [26] effects of $\mu$-opioid receptor were greatly enhanced after repeated AMPH or METH treatment, suggesting functional alterations in $\mu$-opioid receptors. Taken together with the findings above, $\mu$-opioid receptors seem to play a major role in modulating or mediating the effects of psychostimulants in the mesolimbic dopamine system and susceptible to repeated psychostimulant treatment. Therefore, the present study was designed to extend our research by addressing the question whether alterations in $\mu$-opioid receptor are associated with the induction and expression of METH-induced behavioral sensitization. 


\section{Materials and methods}

\section{Materials}

$\left[{ }^{3} \mathrm{H}\right]-\left[\mathrm{D}-\mathrm{Ala}^{2}, \quad N\right.$-Me-Phe ${ }^{4}, \quad \mathrm{Gly}^{5}$-ol]-enkephalin $\left(\left[{ }^{3} \mathrm{H}\right]\right.$-DAMGO; $\left.50 \mathrm{Ci} / \mathrm{mmol}\right), \quad\left[{ }^{3} \mathrm{H}\right]-\left[\mathrm{D}-\mathrm{Pen}^{2,5}\right]-$ enkephalin $\left(\left[{ }^{3} \mathrm{H}\right]\right.$-DPDPE; $\left.45 \mathrm{Ci} / \mathrm{mmol}\right),\left[{ }^{3} \mathrm{H}\right]-(5 \alpha$, $7 \alpha, 8 \beta)$ - (+)- $N$-methyl- $N$-(7-[1-pyrrolidinyl]-1-ox aspiro[4.5]dec-8-yl)-benzeneacetamide $\left(\left[{ }^{3} \mathrm{H}\right]-\mathrm{U} 69\right.$, $593 ; 39.7 \mathrm{Ci} / \mathrm{mmol})$, and guanosine $5^{\prime}-O-\left(3-\left[{ }^{35} \mathrm{~S}\right]-\right.$ thio) triphosphate $\left.\left({ }^{35} \mathrm{~S}\right]-\mathrm{GTP} \gamma \mathrm{S} ; 1250 \mathrm{Ci} / \mathrm{mmol}\right)$, were purchased from Perkin Elmer Inc. (Boston, MA). Scintillation cocktail (Bio-safe II) was obtained from RPI (Mount Prospect, IL). The assay reagent for protein content was purchased from Bio-Rad (Richmond, CA). METH, naloxone, NAT, $\beta$-chlornaltrexamine $(\beta$-CNA), DAMGO, guanosine $5^{\prime}$-diphosphate (GDP), GTP $\gamma \mathrm{S}$, and all other chemicals, were purchased from Sigma-Aldrich (St. Louis, MO).

\section{Animals}

Male NIH Swiss mice (Harlan, Indianapolis, IN), weighing $20-25 \mathrm{~g}$ at the beginning of the experiment were used. Upon arrival, mice were housed in groups of four in animal colony room on a 12 -h light-dark cycle, and at constant temperature $\left(22 \pm 2{ }^{\circ} \mathrm{C}\right)$. Before any treatment, mice were maintained in the colony room for at least 7 days without disturbance. $\mu$-Opioid receptor knockout mice used in this study were developed by Loh et al. [27] and maintained on a 1:1 hybrid genetic background (C57/BL6 and 129/Ola) as described. Food and water were available ad libitum. All procedures for animal handling and experiments were approved by Institutional Animal Care Committee of the University of Mississippi Medical Center, and performed in compliance with the NIH Guide for the Care and Use of Laboratory Animals.

\section{Induction of behavioral sensitization}

For induction of behavioral sensitization, each mouse was injected i.p. with either $2.5 \mathrm{mg} / \mathrm{kg}$ of METH (sensitized group) or saline (control nonsensitized group) once a day for seven consecutive days. Mice were kept in animal colony room and received all injections in their home cages. Our previous study demonstrated that this treatment regimen of METH successfully induced longlasting behavioral sensitization in mice (at least 3 weeks after the cessation of the drug treatment) [11]. METH was freshly dissolved in saline before use and injected at a volume of $10 \mathrm{ml} / \mathrm{kg}$ of body weight.

\section{Brain membrane preparations}

To investigate the neuronal alterations induced by repeated METH treatment during the induction period (days 1-7), brain samples were obtained $24 \mathrm{~h}$ after the first, fourth, and last daily injections of saline or METH on days 2, 5, and 8, respectively, for the purpose of preventing the possible interference produced by acute effect of the drug. For studies of the neuronal alterations associated with the expression of behavioral sensitization after short-term and long-term periods of abstinence, brain samples were obtained on days 11 and 21, respectively. Mice received 7 days of repeated METH treatment without behavioral testing were assumed to be sensitized with the same consideration. $\mu$-Opioid receptor knockout and wild-type mice were sacrificed without any treatment. Mice were sacrificed by decapitation and the brains were removed and frozen immediately in liquid nitrogen for $14 \mathrm{~s}$. Whole brains without cerebella were homogenized in 30 volumes of ice-cold homogenizing buffer $\left(50 \mathrm{mM}\right.$ Tris- $\mathrm{HCl}, 3 \mathrm{mM} \mathrm{MgCl}_{2}$, $1 \mathrm{mM}$ EGTA, pH 7.4 at $4{ }^{\circ} \mathrm{C}$ ). The membrane homogenates were incubated for $20 \mathrm{~min}$ at $37^{\circ} \mathrm{C}$ to remove endogenous ligand and washed twice with the same buffer by centrifugation $(49,000 \times$ $\mathrm{g}$ for $20 \mathrm{~min}$ at $4{ }^{\circ} \mathrm{C}$ ) and re-suspension. After the last centrifugation, the brain membranes were suspended in the homogenizing buffer containing $0.32 \mathrm{M}$ sucrose and stored at $-80{ }^{\circ} \mathrm{C}$ until use. The protein content was measured using reagent purchased from Bio-Rad (Richmond, CA).

\section{Saturation analysis of radioligand binding in brain membranes}

All binding experiments were performed in $50 \mathrm{mM}$ Tris- $\mathrm{HCl}$ buffer $(\mathrm{pH}$ 7.4) in a final volume of $0.5 \mathrm{ml}$ containing $80-120 \mu \mathrm{g}$ of membrane protein. For total binding, aliquots of membrane homogenates were assayed in tubes containing 0.05-8 $\mathrm{nM}$ of $\left[{ }^{3} \mathrm{H}\right]$-DAMGO, $\left[{ }^{3} \mathrm{H}\right]$-DPDPE, or $\left[{ }^{3} \mathrm{H}\right]-\mathrm{U} 69,593$ for the labeling of $\mu$-, $\delta$-, or $\kappa$-opioid 
receptors, respectively. Non-specific binding was determined in the presence of $10 \mu \mathrm{M}$ of naloxone under identical conditions. Tubes were incubated for $90 \mathrm{~min}$ at $25^{\circ} \mathrm{C}$ and the reactions were terminated by rapid filtration through Whatman $\mathrm{GF} / \mathrm{B}$ filters in a cell harvester. Filters were washed three times with $3 \mathrm{ml}$ of ice-cold Tris- $\mathrm{HCl}$ buffer $(50 \mathrm{mM}, \mathrm{pH} 7.7)$ and transferred into vials containing $4 \mathrm{ml}$ of scintillation cocktail. The radioactivity in the samples was determined by a liquid scintillation analyzer (Packard Instrument, Meriden, CT). Specific binding values were calculated by subtracting non-specific binding from total binding values. All experiments were performed in duplicate using pooled brain membranes from three mice and the results were obtained from four independent experiments with different groups of animals.

\section{$\left[{ }^{35} S\right]-G T P \gamma S$ coupling in brain membranes}

For investigating concentration effect of $\mu$-opioid receptor agonist-stimulated $\left[{ }^{35} \mathrm{~S}\right]-\mathrm{GTP} \gamma \mathrm{S}$ coupling, aliquots $(\sim 15 \mu \mathrm{g}$ of protein) of brain membrane homogenates were assayed in the buffer $(50 \mathrm{mM}$ Tris- $\mathrm{HCl}, 3 \mathrm{mM} \mathrm{MgCl}_{2}, 1 \mathrm{mM}$ DTT, $1 \mathrm{mM}$ EGTA, $100 \mathrm{mM} \mathrm{NaCl}, 0.1 \%$ BSA, pH 7.5) containing $100 \mu \mathrm{M}$ GDP, $0.1 \mathrm{nM}\left[{ }^{35} \mathrm{~S}\right]-\mathrm{GTP} \gamma \mathrm{S}$, and different concentrations $(1 \mathrm{nM}$ to $10 \mu \mathrm{M})$ of DAMGO in a final volume of $0.5 \mathrm{ml}$. Constitutive activity of $\mu$-opioid receptor was determined by adding $1 \mu \mathrm{M}$ of NAT, a non-selective opioid receptor antagonist, or $1 \mu \mathrm{M}$ of $\beta$-CNA, an antagonist of $\mu$-opioid receptor with negative intrinsic activity (inverse agonist) [28], into the assay buffer containing $10 \mu \mathrm{M}$ GDP. With the concentration of $1 \mu \mathrm{M}$, both agents have been reported to specifically suppress the constitutive activity of $\mu$-opioid receptor in mice brain homogenates [29]. Changes in constitutive activity were revealed by changes in the effects of antagonists on $\left[{ }^{35} \mathrm{~S}\right]-$ GTP $\gamma \mathrm{S}$ coupling. Basal coupling was determined in the absence of agonist or antagonist and non-specific coupling was determined in the presence of $10 \mu \mathrm{M}$ of unlabeled GTP $\gamma \mathrm{S}$. All preparations were incubated for $90 \mathrm{~min}$ at $25^{\circ} \mathrm{C}$ and reactions were terminated by rapid filtration through Whatman GF/B filters in a cell harvester. Filters were washed three times with $3 \mathrm{ml}$ of icecold buffer $(50 \mathrm{mM}$ Tris- $\mathrm{HCl}, 50 \mathrm{mM} \mathrm{NaCl}$, $\mathrm{pH}$ 7.7) and transferred into vials containing
$4 \mathrm{ml}$ of scintillation cocktail. Net $\left[{ }^{35} \mathrm{~S}\right]-\mathrm{GTP} \gamma \mathrm{S}$ coupling values were calculated by subtracting non-specific coupling values. Drug-stimulated changes in $\left[{ }^{35} \mathrm{~S}\right]-\mathrm{GTP} \gamma \mathrm{S}$ coupling values were expressed as $\%$ of basal coupling values under identical conditions. All experiments were performed in triplicate using pooled brain membranes from three mice and the results were obtained from at least five independent experiments with different groups of animals.

\section{Data analysis}

The parameters $\left(K_{\mathrm{d}}\right.$ and $\left.B_{\max }\right)$ of radioligand binding were obtained from non-linear regression analysis of saturation binding curve, using GraphPad Prism 3.02 (GraphPad Software, San Diego, $\mathrm{CA})$. The $\mathrm{EC}_{50}$ of DAMGO for $\left[{ }^{35} \mathrm{~S}\right]-\mathrm{GTP} \gamma \mathrm{S}$ coupling was obtained from non-linear regression analysis of sigmoidal concentration-response curve using the same computer software. The effects of METH on alterations in opioid receptors during the induction or expression periods of behavioral sensitization were analyzed by two-way analysis of variance (ANOVA) followed by Bonferroni post-tests, using SigmaStat 3.0 (SPSS Science, Rochester, MN). Data are expressed as mean \pm standard errors of the mean (S.E.M.).

\section{Results}

Effects of METH on receptor binding during the induction period of behavioral sensitization

To investigate whether repeated METH treatment produces alteration in opioid receptors, we first determined the changes in $\mu$-opioid receptor binding during the induction period on days 2,5 , and 8 , as described in methods. Saturation analysis of radioligand binding revealed that repeated saline treatment did not affect either the $B_{\max }$ (the maximum number of binding sites, fmol $/ \mathrm{mg}$; day $2,323 \pm 9$; day $5,313 \pm 14$; day $8,327 \pm 10$ ) or $K_{\mathrm{d}}$ (binding affinity, $\mathrm{nM}$; day $2,1.4 \pm 0.2$; day $5,1.1 \pm 0.1$; day $8,1.3 \pm 0.1$ ) values of $\left[{ }^{3} \mathrm{H}\right]-$ DAMGO to $\mu$-opioid receptor binding. Similar $K_{\mathrm{d}}$ values were also obtained in the brain from METH-pretreated mice across the days examined (day 2, $1.2 \pm 0.1$; day $5,1.1 \pm 0.1$; day 8 , $1.4 \pm 0.2)$. However, a two-way ANOVA 
$($ METH treatment $\times$ days of treatment) revealed significant effects for $B_{\max }$ values (METH treatment: $F[1,18]=5.48, p=0.031$; interaction: $F[2,18]=4.23, p=0.031)$. Compared with the corresponding saline-pretreated control group, the $B_{\max }$ values of $\left[{ }^{3} \mathrm{H}\right]$-DAMGO binding in the brain from METH-pretreated mice were nearly unchanged on days $2(315 \pm 18$; Figure 1a) and 5 (316 \pm 9; Figure 1b), but decreased significantly with prolonged METH treatment on day 8 (277 $\pm 9 ; \sim 85 \%$ of control, $p<0.05$, Bonferroni post-test; Figure 1c). To further investigate potential alterations in other types of opioid receptors, radioligands $\left[{ }^{3} \mathrm{H}\right]$-DPDPE and $\left[{ }^{3} \mathrm{H}\right]-\mathrm{U} 69,593$ were used for the labeling of $\delta$ - and $\kappa$-opioid receptors, respectively. Compared with the corresponding saline-pretreated group, no significant changes in $B_{\max }$ or $K_{\mathrm{d}}$ values for $\left[{ }^{3} \mathrm{H}\right]$-DPDPE (saline vs. METH, $B_{\max }$ and $K_{\mathrm{d}}$, respectively: day $2,372 \pm$
31 and $6.4 \pm 0.5$ vs. $346 \pm 35$ and $6.2 \pm 0.5$; day $5,347 \pm 33$ and $6.0 \pm 0.2$ vs. $353 \pm 38$ and $6.7 \pm 0.6$; day $8,365 \pm 48$ and $6.6 \pm 0.9$ vs. $338 \pm 66$ and $6.4 \pm 1.1)$ and $\left[{ }^{3} \mathrm{H}\right]-\mathrm{U} 69,593$ (day $2,70 \pm 6$ and $2.1 \pm 0.2$ vs. $81 \pm 5$ and $2.6 \pm 0.2$; day $5,65 \pm 12$ and $1.8 \pm 0.3$ vs. 87 \pm 19 and $2.5 \pm 0.5$; day $8,75 \pm 3$ and $2.2 \pm$ 0.2 vs. $72 \pm 3$ and $1.9 \pm 0.1$ ) binding were detectable in the brain from METH-pretreated mice on any given day tested (Figure 1a-c).

\section{Effects of METH on receptor binding during the expression period of behavioral sensitization}

Next, we determined whether alterations in $\mu$-opioid receptor are associated with the expression of METH-induced behavioral sensitization after short- and long-term periods of abstinence on days 11 and 21, respectively. During the expression
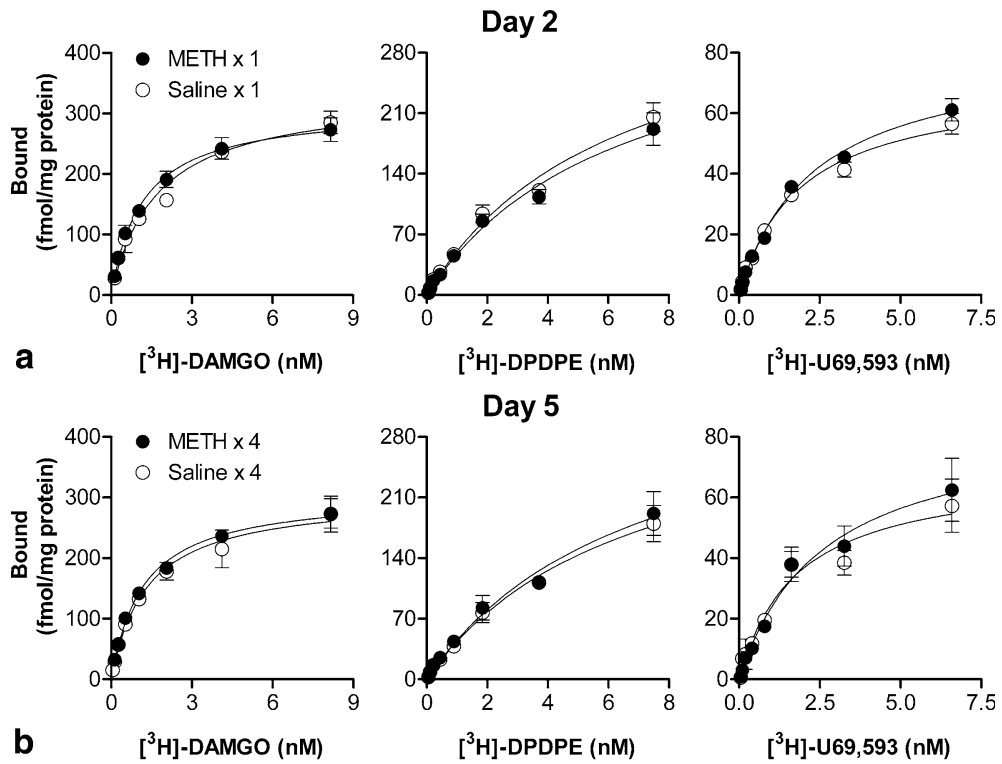

Day 5
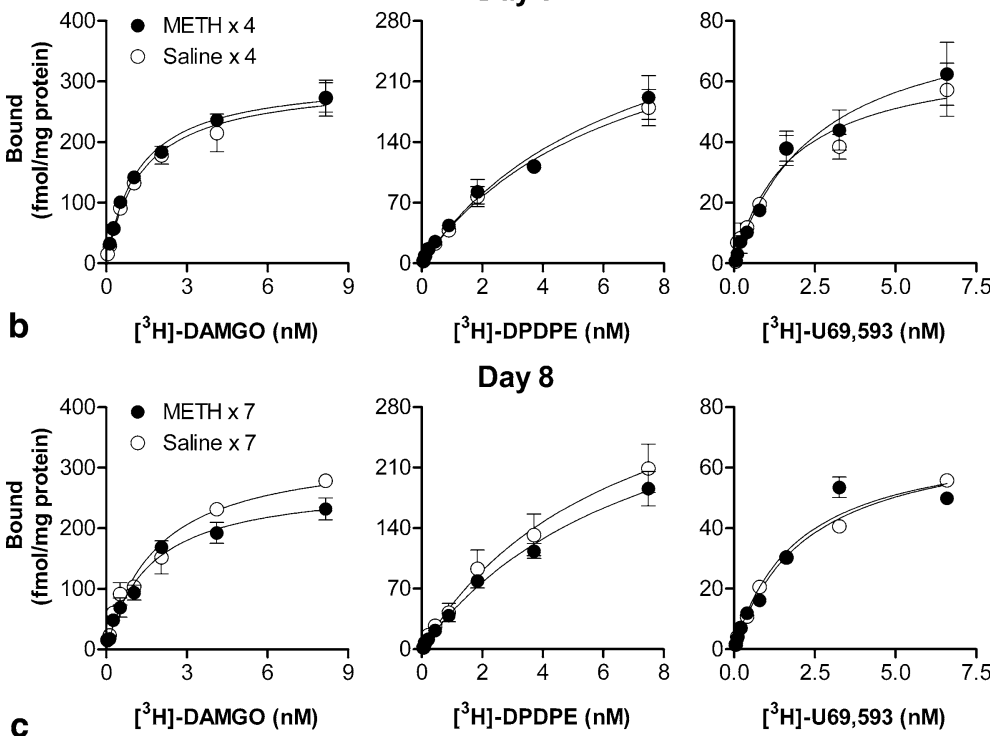

Figure 1. Effects of METH on receptor binding in brain membranes during the induction period. Saturation analyses of radioligand binding using $\left[{ }^{3} \mathrm{H}\right]-\mathrm{DAMGO},\left[{ }^{3} \mathrm{H}\right]$-DPDPE, or $\left[{ }^{3} \mathrm{H}\right]-\mathrm{U} 69,593$ were performed in the brain from mice $24 \mathrm{~h}$ after the first, fourth, and last daily injections of saline or METH on days 2 (a), 5 (b), and 8 (c), respectively. Data are mean values (mean \pm S.E.M.) of four independent experiments. 
periods, no changes in the $B_{\max }$ and $K_{\mathrm{d}}$ values of $\left[{ }^{3} \mathrm{H}\right]$-DAMGO binding were observed in the brain from non-sensitized (saline-pretreated) mice ( $B_{\max }$ and $K_{\mathrm{d}}$, respectively: day $11,311 \pm 7$ and $1.3 \pm 0.1$; day $21,317 \pm 13$ and $1.2 \pm 0.2$ ), and similar $K_{\mathrm{d}}$ values were also obtained from sensitized (METH-pretreated) mice (day 11, $1.2 \pm 0.1$; day $21,1.3 \pm 0.2$ ). However, a twoway ANOVA (METH treatment $\times$ days of abstinence) revealed significant effects for $B_{\max }$ values (METH treatment: $F[1,12]=12.42, p=0.004$; days of abstinence: $F[1,12]=5.52, p=0.037$ ). The $B_{\max }$ value of $\left[{ }^{3} \mathrm{H}\right]$-DAMGO binding in the brain from sensitized mice after a short-term period of abstinence was returned, from downregulated on day 8 , to normal level on day 11 (334 $\pm 23 ; \sim 111 \%$ of control, this value did not reach statistical significance; Figure 2a). After a longer period of abstinence on day 21 , the $B_{\max }$ value of $\left[{ }^{3} \mathrm{H}\right]$-DAMGO binding in the brain from sensitized mice was up-regulated when compared with the corresponding non-sensitized control group (393 $\pm 10 ; \sim 124 \%$ of control, $p<0.01$, Bonferroni post-test; Figure 2b). In contrast, the $B_{\max }$ or $K_{\mathrm{d}}$ values for $\left[{ }^{3} \mathrm{H}\right]$-DPDPE (non-sensitized vs. sensitized, $B_{\max }$ and $K_{\mathrm{d}}$, respectively: day 11 , $398 \pm 17$ and $6.1 \pm 0.9$ vs. $388 \pm 29$ and
$6.7 \pm 0.9$; day $21,349 \pm 13$ and $5.1 \pm 0.4$ vs. $363 \pm 24$ and $4.8 \pm 0.2$ ) and $\left[{ }^{3} \mathrm{H}\right]-\mathrm{U} 69,593$ (day $11,76 \pm 5$ and $2.1 \pm 0.3$ vs. $85 \pm 9$ and $2.2 \pm 0.5$; day $21,75 \pm 6$ and $2.1 \pm 0.3$ vs. $83 \pm 6$ and $2.5 \pm 0.2$ ) binding remained unchanged in sensitized mice at these time points tested (Figure 2a, b). These results support the hypothesis that alterations in $\mu$-opioid receptor are involved in METH-induced behavioral sensitization and indicate that $\mu$-opioid receptors are the most sensitive to repeated METH treatment. Therefore, we only focused on the alterations in $\mu$-opioid receptor in the following functional studies.

\section{Effects of METH on DAMGO-stimulated $\left[{ }^{35} S\right]-G T P \gamma S$ coupling during the induction period}

Exchange of GDP for GTP is the first step in G protein-coupled receptor signaling and $\mu$-opioid receptors are negatively coupled to adenylyl cyclase via $G_{i} / G_{o} \alpha$ proteins. Thus, to further investigate whether repeated METH treatment produces functional alterations in $\mu$-opioid receptor, different concentrations of $\mu$-opioid receptor agonist DAMGO, ranging from $1 \mathrm{nM}$ to $10 \mu \mathrm{M}$, were used to determine the changes in potency
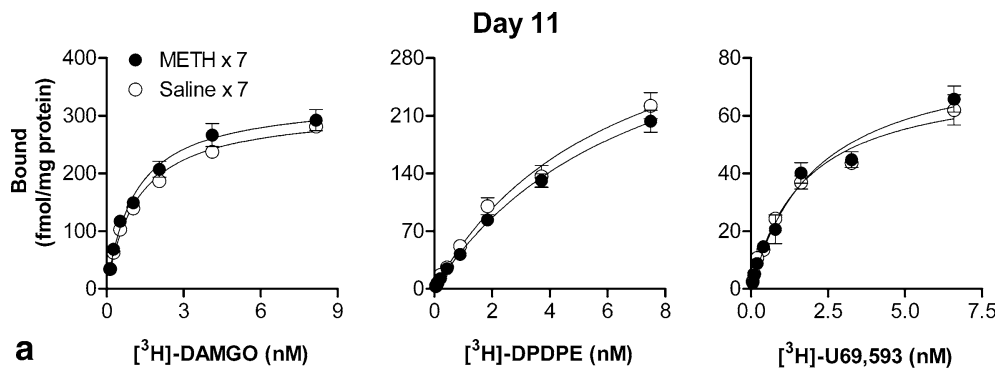

Day 21
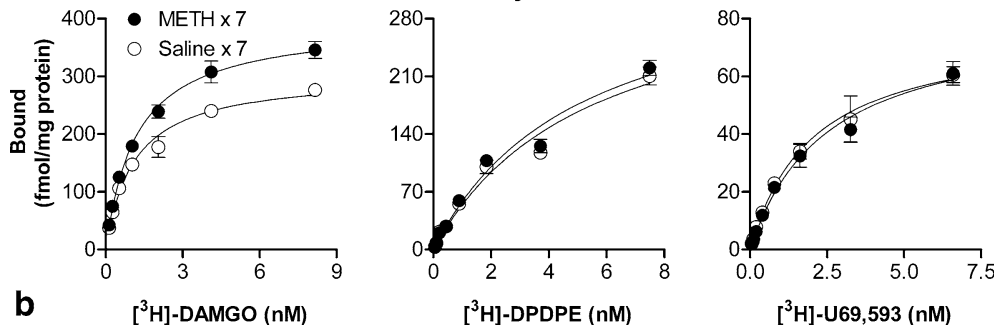

Figure 2. Effects of METH on receptor binding in brain membranes during the expression period. Saturation analyses of radioligand binding using $\left[{ }^{3} \mathrm{H}\right]$-DAMGO, $\left[{ }^{3} \mathrm{H}\right]$-DPDPE, or $\left[{ }^{3} \mathrm{H}\right]-\mathrm{U} 69,593$ were performed in the brain from saline- or METH-pretreated mice after short-term and long-term periods of abstinence on days 11 (a) and 21 (b), respectively. Data are mean values (mean \pm S.E.M.) of four independent experiments. 
$\left(E_{50}\right)$ and efficacy of the agonist for receptor activation. During the induction period investigated, addition of DAMGO into the brain membranes from saline-pretreated mice produced similar increase in $\left[{ }^{35} \mathrm{~S}\right]-\mathrm{GTP} \gamma \mathrm{S}$ coupling by $\sim 50 \%$ with no significant changes in the $\mathrm{EC}_{50}$ values $(\mathrm{nM}$; day 2, $714 \pm 90$; day $5,734 \pm 132$; day 8, $747 \pm 51$; Figure $3 \mathrm{a}-\mathrm{c}$ ). The lack of DAMGO effect on brain membranes from $\mu$-opioid receptor gene knockout mice confirmed that the increase in $\left[{ }^{35} \mathrm{~S}\right]$-GTP $\gamma \mathrm{S}$ coupling was resulted from $\mu$-opioid receptor activation (Figure 4). Repeated METH treatment did not affect the maximal responses (efficacy) induced by DAMGO, whereas the concentration-response curves for DAMGO shifted to the left on days 2 (Figure 3a) and 5 (Figure 3b), but did not after prolonged METH treatment on day 8 (Figure 3c). A two-way ANOVA (METH treatment $\times$ days of treatment) revealed significant effects for $\mathrm{EC}_{50}$ values of DAMGO (METH treatment: $F[1,30]=22.70, p<0.001$; days of treatment: $F[2,30]=3.55, p=0.041)$. Compared with the corresponding saline-pretreated group, the $\mathrm{EC}_{50}$ values were significantly decreased in the brain from METH-treated mice on days 2 (262 $\pm 36 ; p<0.01$, Bonferroni post-test) and 5 (368 \pm 84; $p<0.01$, Bonferroni post-test), but nearly unchanged on day $8(641 \pm 40)$.

\section{Effects of METH on DAMGO-stimulated $\left[{ }^{35} S\right]-G T P \gamma S$ coupling during the expression period}

Next, DAMGO-induced $\left[{ }^{35} \mathrm{~S}\right]-\mathrm{GTP} \gamma \mathrm{S}$ coupling were performed in brain membranes from mice on days 11 and 21 to investigate whether functional alterations in $\mu$-opioid receptor are associated with the expression of behavioral sensitization after short-term and long-term periods of abstinence, respectively. During the expression periods, addition of DAMGO into the brain membranes from non-sensitized mice produced similar increase in $\left[{ }^{35} \mathrm{~S}\right]-\mathrm{GTP} \gamma \mathrm{S}$ coupling with no significant changes in the $E C_{50}$ values (day 11, $719 \pm 50$; day 21, $728 \pm 23$; Figure 5a, b). Similar maximal responses induced by DAMGO were also observed in brain membranes from sensitized mice; nevertheless, a two-way ANOVA (METH treatment $\times$ days of abstinence) revealed significant effects for $\mathrm{EC}_{50}$ values $(\mathrm{METH}$ treatment: $F[1,20]=44.62, p<0.001 ;$ days

\section{Day 2}

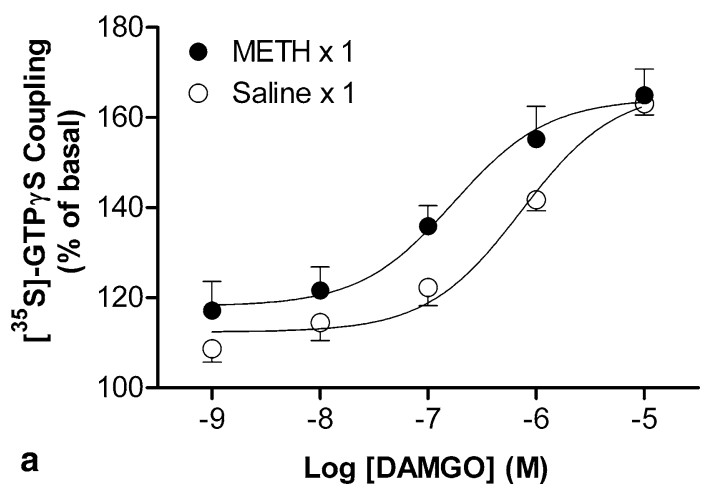

\section{Day 5}

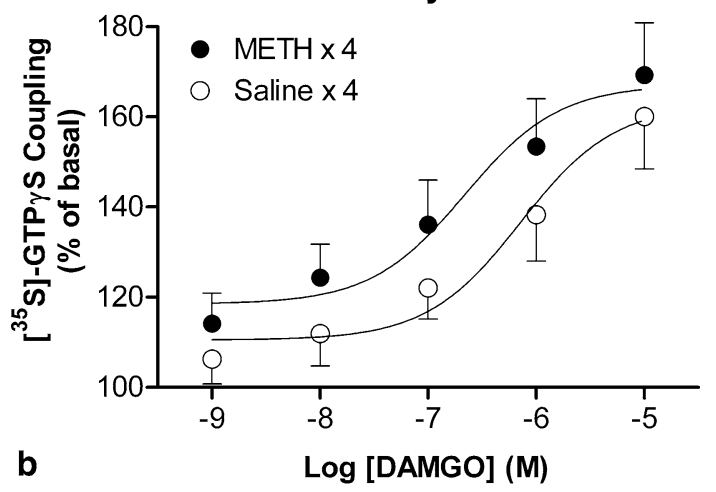

\section{Day 8}

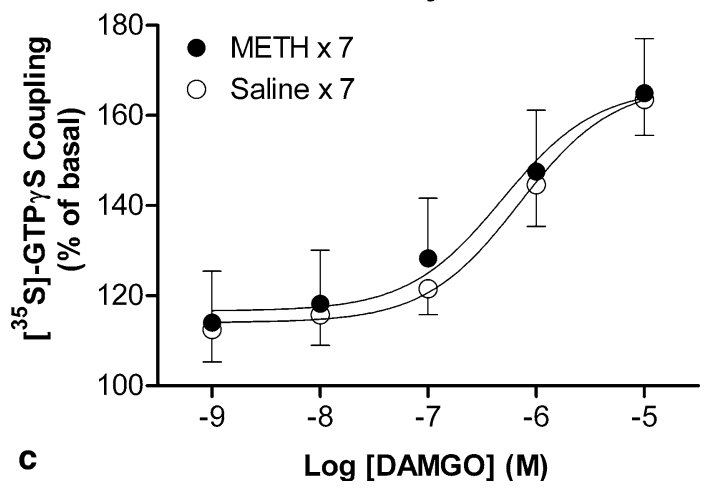

Figure 3. Effects of METH on DAMGO-stimulated $\left[{ }^{35} \mathrm{~S}\right]-\mathrm{GTP} \gamma \mathrm{S}$ coupling in brain membranes during the induction period. $\left[{ }^{35} \mathrm{~S}\right]-\mathrm{GTP} \gamma \mathrm{S}$ coupling concentration-response curves for DAMGO were obtained in the brain from mice $24 \mathrm{~h}$ after the first, fourth, and last daily injections of saline or METH on days 2 (a), 5 (b), and 8 (c), respectively. Data are expressed as $\%$ of basal level (mean \pm S.E.M.) under identical conditions of six independent experiments.

of abstinence: $F[1,20]=10.61, \quad p=0.004$; interaction: $F[1,20]=12.13, p=0.002)$. Compared with the corresponding non-sensitized 


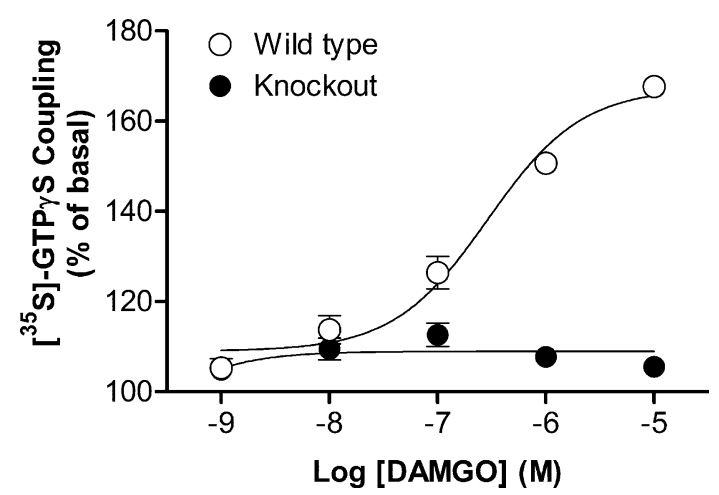

Figure 4. DAMGO-stimulated $\left[{ }^{35} \mathrm{~S}\right]-\mathrm{GTP} \gamma \mathrm{S}$ coupling in wild-type and $\mu$-opioid receptor knockout mice. $\left[{ }^{35} \mathrm{~S}\right]-\mathrm{GTP} \gamma \mathrm{S}$ coupling concentration-response curves for DAMGO were obtained in the brain from wild-type and $\mu$-opioid receptor knockout mice without any treatment. Data are expressed as $\%$ of basal level (mean \pm S.E.M.) under identical conditions of three independent experiments.

Day 11

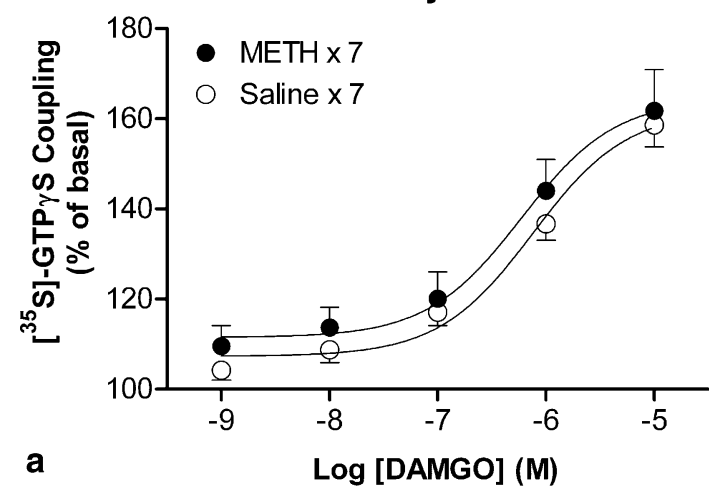

Day 21

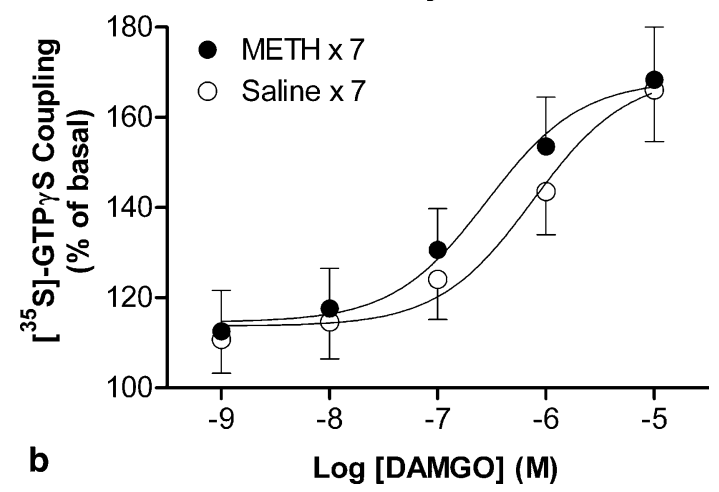

Figure 5. Effects of METH on DAMGO-stimulated $\left[{ }^{35} \mathrm{~S}\right]-$ $\mathrm{GTP} \gamma \mathrm{S}$ coupling in brain membranes during the expression period. $\left[{ }^{35} \mathrm{~S}\right]-\mathrm{GTP} \gamma \mathrm{S}$ coupling concentration-response curves for DAMGO were obtained in the brain from saline- or METH-pretreated mice after short-term and long-term periods of abstinence on days 11 (a) and 21 (b), respectively. Data are expressed as $\%$ of basal level (mean \pm S.E.M.) under identical conditions of six independent experiments. group, the $\mathrm{EC}_{50}$ value of DAMGO for $\left[{ }^{35} \mathrm{~S}\right]-$ GTP $\gamma$ S coupling was decreased modestly in sensitized mice after a short-term period of abstinence on day $11(597 \pm 28 ; p<0.05$, Bonferroni posttest; Figure 5a). With the concentration-response curve shifting to the left, the $\mathrm{EC}_{50}$ value was decreased further in sensitized mice after a longer period of abstinence on day 21 (341 \pm 46 ; $p<0.01$, Bonferroni post-test; Figure 5b).

\section{Effects of METH on the constitutive activity} of $\mu$-opioid receptor during the induction period

Many G protein-coupled receptors, including $\mu$-opioid receptor, exhibit constitutive activity which produces spontaneous regulation of $G$ proteins and effectors in the absence of activation by agonists $[28,30]$. Recent in vitro $[28,30]$ and in vivo [29] studies found that chronic activation of $\mu$-opioid receptor by morphine treatment increased such agonist-independent activity. By suppressing the elevated constitutive activity, the property of NAT was found from neutral antagonist in untreated cells, to turn into inverse agonist (antagonist with negative intrinsic activity) in cells after chronic morphine treatment. Moreover, as an irreversible antagonist, $\beta$-CNA was reported to serve as an inverse agonist and specifically suppress the constitutive activity of $\mu$-opioid receptor [28]. To investigate whether repeated METH treatment affects the constitutive activity of $\mu$-opioid receptor, the effects of these antagonists on basal $\left[{ }^{35} \mathrm{~S}\right]-\mathrm{GTP} \gamma \mathrm{S}$ coupling were determined.

Addition of NAT $(1 \mu \mathrm{M})$ into brain membranes from saline-pretreated mice slightly increased $\left[{ }^{35} \mathrm{~S}\right]-\mathrm{GTP} \gamma \mathrm{S}$ coupling (open bars; Figure 6a). A two-way ANOVA (METH treatment $\times$ days of treatment) revealed significant effects for NAT-induced $\left[{ }^{35} \mathrm{~S}\right]-\mathrm{GTP} \gamma \mathrm{S}$ coupling (METH treatment: $F[1,30]=7.45, p=0.001$ ). Compared with the corresponding saline-pretreated group, NAT significantly suppressed the basal $\left[{ }^{35} \mathrm{~S}\right]$-GTP $\gamma \mathrm{S}$ coupling in brain membranes from mice received a single METH injection on day 2 $(p<0.01$, Bonferroni post-test). The NAT-induced decrease in basal $\left[{ }^{35} \mathrm{~S}\right]-\mathrm{GTP} \gamma \mathrm{S}$ coupling indicates inverse agonist activity of the antagonist and suggests the presence of constitutive activity. Although NAT also appeared to suppress the basal $\left[{ }^{35} \mathrm{~S}\right]-\mathrm{GTP} \gamma \mathrm{S}$ coupling in METH-pretreated 
mice on days 5 and 8, they were not statistically significant (closed bars; Figure 6a).

To further identify whether this elevated constitutive activity was resulted from $\mu$-opioid receptor, the effects of $\beta$-CNA on basal $\left[{ }^{35} \mathrm{~S}\right]-\mathrm{GTP} \gamma \mathrm{S}$ coupling were determined. Addition of $\beta$-CNA $(1 \mu \mathrm{M})$ produced similar agonist-like effects in saline-pretreated mice as did by NAT (open bars; Figure 6b). The lack of inhibitory effect of $\beta$-CNA on basal $\left[{ }^{35} \mathrm{~S}\right]-\mathrm{GTP} \gamma \mathrm{S}$ coupling indicates that no constitutive activity of $\mu$-opioid receptor was detectable in saline-pretreated mice under the experimental conditions used. However, a two-way ANOVA (METH treatment $\times$ days of treatment) revealed significant effects for $\beta$-CNAinduced $\left[{ }^{35} \mathrm{~S}\right]-\mathrm{GTP} \gamma \mathrm{S}$ coupling (METH treatment: $F[1,30]=6.38, p=0.017)$. Consistent with the results produced by NAT, $\beta$-CNA significantly suppressed the basal $\left[{ }^{35} \mathrm{~S}\right]-\mathrm{GTP} \gamma \mathrm{S}$ coupling in METH-pretreated mice on day $2(p<0.05$, Bonferroni post-test), but not on days 5 and 8 (closed bars; Figure $6 \mathrm{~b}$ ). The $\beta$-CNA-induced decrease in basal $\left[{ }^{35} \mathrm{~S}\right]-\mathrm{GTP} \gamma \mathrm{S}$ coupling confirms enhanced

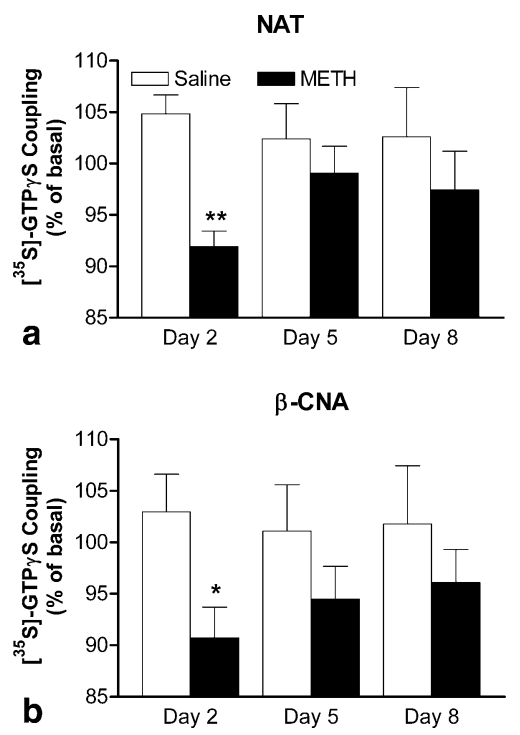

Figure 6. Effects of antagonists on basal $\left[{ }^{35} \mathrm{~S}\right]-\mathrm{GTP} \gamma \mathrm{S}$ coupling in brain membranes during the induction period. Effects of NAT (a) and $\beta$-CNA (b) were determined in the brain from mice $24 \mathrm{~h}$ after the first, fourth, and last daily injections of saline or METH on days 2, 5, and 8, respectively. Data are expressed as $\%$ of basal level (mean \pm S.E.M.) under identical conditions $(n=6) .{ }^{*} p<0.05,{ }^{* *} p<0.01$, compared with response of corresponding saline-pretreated group, according to Bonferroni post-tests after a two-way ANOVA (METH treatment $\times$ days of treatment). constitutive activity of $\mu$-opioid receptor after a single METH treatment.

\section{Effects of METH on the constitutive activity of $\mu$-opioid receptor during the expression period}

Next, the effects of $1 \mu \mathrm{M}$ of NAT and $\beta$-CNA on basal $\left[{ }^{35} \mathrm{~S}\right]-\mathrm{GTP} \gamma \mathrm{S}$ coupling were determined to investigate whether alterations in constitutive activity of $\mu$-opioid receptor are associated with the expression of behavioral sensitization. In brain membranes from non-sensitized mice on days 11 and 21 (open bars in figures), both agents produced similar agonist-like effects on $\left[{ }^{35} \mathrm{~S}\right]-\mathrm{GTP} \gamma \mathrm{S}$ coupling (Figure $7 \mathrm{a}, \mathrm{b}$ ), indicating that no constitutive activity was detectable. In contrast, two-way ANOVA (METH treatment $\times$ days of abstinence) revealed significant effects for NAT- (METH treatment: $F[1,16]=18.331, p<0.001)$ and $\beta$-CNAinduced $\left[{ }^{35} \mathrm{~S}\right]-\mathrm{GTP} \gamma \mathrm{S}$ coupling (METH treatment: $F[1,16]=12.15, p=0.003)$. Compared with the corresponding non-sensitized group, the $\left[{ }^{35} \mathrm{~S}\right]$ -
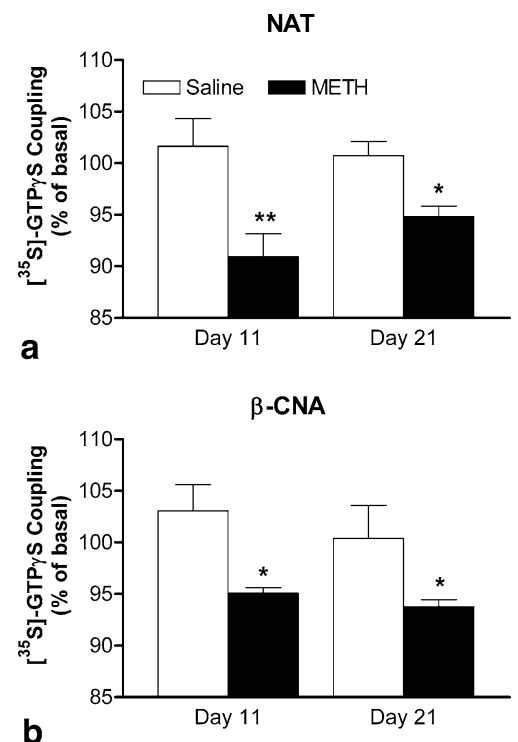

Figure 7. Effects of antagonists on basal $\left[{ }^{35} \mathrm{~S}\right]-\mathrm{GTP} \gamma \mathrm{S}$ coupling in brain membranes during the expression period. Effects of NAT (a) and $\beta$-CNA (b) were determined in the brain from saline- or METH-pretreated mice after short-term and long-term periods of abstinence on days 11 and 21, respectively. Data are expressed as \% of basal level (mean \pm S.E.M.) under identical conditions $(n=5) . \quad{ }^{*} p<0.05$, $* * p<0.01$, compared with response of corresponding salinepretreated group, according to Bonferroni post-tests after a two-way ANOVA (METH treatment $x$ days of abstinence). 
$\mathrm{GTP} \gamma \mathrm{S}$ coupling in brain membranes from sensitized mice (closed bars in figures) on day 11 were significantly suppressed by NAT $(p<0.01$, Bonferroni post-test; Figure 7a) or $\beta$-CNA $(p<0.05$, Bonferroni post-test; Figure $7 b$ ), suggesting the presence of constitutive activity of $\mu$-opioid receptor. The $\left[{ }^{35} \mathrm{~S}\right]-\mathrm{GTP} \gamma \mathrm{S}$ coupling remained to be suppressed by NAT or $\beta$-CNA in sensitized mice after a longer period of abstinence on day 21 $(p<0.05$, Bonferroni post-test). These results indicate that elevated constitutive activity of $\mu$-opioid receptor was associated with the expression of METH-induced behavioral sensitization.

\section{Discussion}

As described in previous section, acute administration of AMPH or METH increased endogenous opioid contents in the brain and suggested the activation of $\mu$-opioid receptors by these endogenous opioids. Therefore, it is reasonable to assume that repeated or prolonged activation of $\mu$-opioid receptor by these endogenous opioids may ultimately lead to receptor down-regulation, a consequence resembles to those of morphine-induced tolerance and dependence [31]. In agreement with this prediction, we demonstrated that the maximal binding of $\mu$-opioid receptor was not modified during the early stage of the induction period but was down-regulated with prolonged treatment of the drug. This observation is consistent with previous findings in rats that acute d-AMPH had no effect on the expression of $\mu$-opioid receptor mRNA, whereas five intermittent injections of the drug resulted in a significant down-regulation of the receptor mRNA levels in the brain [32].

After the drug treatment was stopped, in contrast, the maximal binding of $\mu$-opioid receptor was gradually recovered, from down-regulation on day 8 , returning to normal levels on day 11 , and upregulation on day 21. Significant up-regulation of $\mu$-opioid receptor was also found in some brain regions following chronic intermittent cocaine administration [33]. A study in rats identified that the expression of AMPH-induced behavioral sensitization was associated with up-regulation of $\mu$-opioid receptor mRNA in the VTA [34]. Evidence in literature suggests that the mechanism leads to up-regulation of $\mu$-opioid receptor after repeated psychostimulant treatment might be mediated, at least in part, through dopamine $\mathrm{D}_{2}$ receptors. Continuous infusion of dopamine $\mathrm{D}_{2}$ but not $\mathrm{D}_{1}$ receptor agonist increased the expression of $\mu$ - but not $\delta$-opioid receptors [35]. Conversely, chronic administration of dopamine $\mathrm{D}_{2}$ receptor antagonists decreased $\mu$-opioid receptor binding in the brain [36]. Furthermore, AMPH- or METHinduced behavioral sensitization was found to associate with enhanced phosphorylation of cAMP response element binding protein (CREB) and expression of transcription factors such as Fos and Jun family proteins $[37,38]$. These transcription factors are components of the AP-1 complex and the consensus binding sites of this complex are known to be located in the promoter region of the $\mu$-opioid receptor gene [39]. The finding that AP-1 binding activity was enhanced in various brain regions after repeated METH treatment [37] supports the idea that METH-induced alteration in expression of $\mu$-opioid receptor might be resulted from the induction of these transcription factors following dopamine receptor activation.

Chronic repeated administration of cocaine resulted in up-regulation of $\mu$ - and $\kappa$-, but not $\delta$-opioid receptors in rats [33]. Moreover, a transient elevated expression of $\delta$-opioid receptor mRNA was found in the VTA after repeated AMPH treatment [34]. Unlike those findings, no changes in $B_{\max }$ or $K_{\mathrm{d}}$ values of $\delta$ - and $\kappa$-opioid receptors were detectable in the present study. The discrepancies may have resulted from differences in subjects, drugs, or experimental conditions. Whatever the differences, it must however be noted that the effects of repeated METH treatment may not globally affect the expression of opioid receptors in the brain, the radioligand binding method using whole brain samples therefore may be insufficient to reveal the region-specific changes in expression of opioid receptors. Although the potential alterations in receptors other than $\mu$-opioid receptors cannot be excluded, the present results not only indicate that $\mu$-opioid receptors are the most sensitive to repeated METH treatment, but also support the hypothesis that $\mu$-opioid receptors are involved in METH-induced behavioral sensitization.

Decrease in the $\mathrm{EC}_{50}$ values of agonist for $\left[{ }^{35} \mathrm{~S}\right]-\mathrm{GTP} \gamma \mathrm{S}$ coupling represents increase in the potency of the agonist as well as the sensitivity of receptor to agonist stimulation. Administration of METH is known to cause overexpression of neuronal nitric oxide synthase in the mouse brain 
[40]. As a second messenger, nitric oxide has been suggested to mediate METH-induced neurotoxicity and behavioral sensitization [41]. It was found that infusion with L-arginine for $8 \mathrm{~h}$, a nitric oxide precursor, did not alter the $B_{\max }$ or $K_{\mathrm{d}}$ values of $\left[{ }^{3} \mathrm{H}\right]$-DAMGO binding to the mouse brain membranes, whereas, it enhanced the efficacy and potency of DAMGO for $\left[{ }^{35} \mathrm{~S}\right]-\mathrm{GTP} \gamma \mathrm{S}$ coupling [42]. These observations are similar to the present study that they were induced by METH treatment. Although no significant differences in efficacy were found, the enhanced potency of DAMGO on days 2 and 5 were not due to METH-induced increases in $\mu$-opioid receptor binding, as the $B_{\max }$ and $K_{\mathrm{d}}$ values for $\left[{ }^{3} \mathrm{H}\right]$-DAMGO binding were not significantly changed on these days tested. Since nitric oxide is known to regulate gene expression by activating diverse signaling pathways [43], it is possible that the enhanced potency of DAMGO in response to METH treatment was resulted from an up-regulation of $G_{i} / G_{o} \alpha$ proteins. In addition, nitric oxide has also been suggested to be involved in opioid desensitization in the CNS [44]. Receptor desensitization was implicated as the mechanism underlying opioid tolerance and dependence, and repeated administration of $\mathrm{L}$-arginine was found to mimic tolerance induced by repeated DAMGO treatment [45]. As the reduction of total membrane receptors was reported to be the major mechanism for functional desensitization of the $\mu$-opioid receptor [46], the decrease in sensitivity of $\mu$-opioid receptor with prolonged METH treatment, from enhanced on day 2 to normal observed on day 8 , might be due to down-regulation of the receptor, as the present results indicated. Although not measured, these findings support the hypothesis that nitric oxide plays a role in mediating METHinduced functional alterations in $\mu$-opioid receptor.

After cessation of repeated METH treatment, the enhanced potency of DAMGO for $\left[{ }^{35} \mathrm{~S}\right]$ GTP $\gamma$ S coupling appeared to be parallel to the changes in the $B_{\max }$ but not $K_{\mathrm{d}}$ values of $\left[{ }^{3} \mathrm{H}\right]$ DAMGO binding during the expression period of sensitization, whereas the changes only evident in potency but not efficacy was unexpected. Due to the experimental or methodological factors, tiny or region-specific changes might not be revealed in the present study. Although the enhanced sensitivity of $\mu$-opioid receptor to agonist stimulation may attribute to the up-regulation of the receptor, the potential changes in expression or binding affinity of $G$ proteins cannot be excluded. Further investigations are required to clear this point.

The observation that inverse agonists decrease basal $G$ protein coupling in membrane preparations is the most convincing evidence demonstrating constitutive activation of $\mu$-opioid receptors. With the concentration of $1 \mu \mathrm{M}, \beta$-CNA has been reported to have negligible non-specific effects in brain homogenates from $\mu$-opioid receptor gene knockout mice, but significantly suppressed basal $\left[{ }^{35} \mathrm{~S}\right]-\mathrm{GTP} \gamma \mathrm{S}$ coupling in those from genetically normal mice, indicating the presence of constitutive activity of $\mu$-opioid receptors in vivo [29]. However, consistent with other research that failed to demonstrate constitutive activity [47], $\beta$-CNA failed to demonstrate constitutive activity in saline-pretreated mice in the present study. The discrepancies may be resulted from differences in subjects or experimental conditions such incubation temperature and incubation time used in these studies. Nonetheless, by making comparisons between saline- and METH-pretreated groups, the basal $\left[{ }^{35} \mathrm{~S}\right]-\mathrm{GTP} \gamma \mathrm{S}$ coupling was significantly suppressed by $1 \mu \mathrm{M}$ of $\beta$-CNA on days 2,11 , and 21 , indicating the elevated constitutive activity of $\mu$-opioid receptors. Moreover, increase in the constitutive activity of $\mu$-opioid receptors has been found to increase the inhibitory effects of antagonists such as naloxone and NAT on basal $\left[{ }^{35} \mathrm{~S}\right]-$ GTP $\gamma \mathrm{S}$ coupling in brain homogenates [29]. Consistent with the observation, our results showed that NAT produced agonist-like effects in brain membranes from saline-pretreated mice, but significantly suppressed the basal $\left[{ }^{35} \mathrm{~S}\right]-\mathrm{GTP} \gamma \mathrm{S}$ coupling in those from METH-pretreated mice on days 2,11 , and 21 .

The mechanism by which METH treatment affects the constitutive activity of $\mu$-opioid receptor is currently unclear. Since acute administration of AMPH or METH is known to increase the content of endogenous opioids, the effects of these endogenous opioids acting presumably at $\mu$-opioid receptors might bear some resemblance to the effects of morphine. However, enhanced constitutive activity of $\mu$-opioid receptor following morphine treatment was found to associate with reduced agonist-stimulated $G$ protein activation [29]. These results seem to be contradictory to the present study that the elevated constitutive activities of the receptor were associated with enhanced potency of DAMGO for $\left[{ }^{35} \mathrm{~S}\right]-\mathrm{GTP} \gamma \mathrm{S}$ 
coupling. It should be mentioned that dopamine receptors were found to exhibit constitutive activity as well [48, 49]. As an indirect dopamine receptor agonist, METH has profound effects on these and even other $\mathrm{G}$ protein-coupled receptors. Therefore, in regard to constitutive activity of $\mu$-opioid receptor, the consequences after repeated METH treatment might be distinct from those after morphine. A study using photolabeling of $\mathrm{G} \alpha$ subunits demonstrated that individual $\mathrm{G}$ proteins activated by constitutively active $\mu$-opioid receptors were different from those by agonist DAMGO [30]. Moreover, a study in mutant $\mu$ opioid receptors which expressed elevated constitutive activity also showed enhanced potency of DAMGO for $\left[{ }^{35} \mathrm{~S}\right]-\mathrm{GTP} \gamma \mathrm{S}$ coupling [50]. These findings may corroborate in part of our observations. Without affecting the maximal binding of the receptor, the elevated constitutive activity at $\mu$ opioid receptors observed on day 2 might also result from an up-regulation of $\mathrm{G}_{\mathrm{i}} / \mathrm{G}_{\mathrm{o}} \alpha$ proteins coupling to the constitutively active receptors. Moreover, owing to a greater chance of encounter of a receptor in the active conformation with $G$ protein, it has been postulated that a high density of receptors would result in a greater degree of constitutive activity [51]. This provides a reasonable explanation for our observations on days 11 and 21 that the elevated constitutive activity at $\mu$ opioid receptors might simply result from the upregulation of the newly synthesized receptors.

The actions of psychostimulants in the VTA are critical for the induction of behavioral sensitization [7]. AMPH and morphine were found to cross-sensitize the locomotor effect of each other's $[52,53]$, and $\mu$-opioid receptor was found to play an important role in morphine-induced behavioral sensitization [54]. Therefore, it is possible that morphine- and METH-induced behavioral sensitization share a common mechanism, activation of $\mu$-opioid receptor. In fact, it has been identified that repeated activation of $\mu$-opioid receptor in the VTA sensitized the mesoaccumbens dopamine neurons to $\mu$-opioid receptor stimulation in the VTA [55, 56] and the locomotor response to AMPH $[8,57]$. With prolonged METH treatment, the desensitization of $\mu$-opioid receptors observed in the present study not only reflects the consequences of persistent activation of $\mu$-opioid receptor, but also supports the hypothesis that $\mu$-opioid receptor contributes to the induction of behavioral sensitization.

The augmentation in dopamine transmission in the NAcc underlies the expression of behavioral sensitization [7], and dopamine $\mathrm{D}_{2}$ receptors play an important role in the expression of sensitized behaviors of AMPH or METH [58, 59]. Several lines of evidence suggest that the locomotor effect of $\mu$-opioid receptor in the VTA is dependent on post-synaptic dopamine $\mathrm{D}_{2}$ receptor $[60,61]$. In addition, tonic activation or the constitutive activity of $\mu$-opioid receptors in the VTA has been found to play a role in maintenance of basal dopamine levels in the NAcc $[15,19]$. Therefore, alterations in the responsiveness of $\mu$-opioid receptor may have profound effect on dopamine $\mathrm{D}_{2}$ receptor-mediated behavior. The elevated constitutive activity of $\mu$-opioid receptor may enhance or maintain the hyperreactivity of mesolimbic dopamine neurons and thereby lower the threshold of locomotor activity triggered by subsequent challenge of METH. In fact, it has been suggested that an increased expression of $\mu$-opioid receptor mRNA in the VTA predisposes animals to a sensitized response to psychostimulant challenge [62]. Moreover, although the locomotor activity induced by $\mu$-opioid receptor stimulation in the NAcc is dopamine-independent [63], the expression of $\mu$-opioid receptor in the NAcc is sensitive to the negative regulatory effect of dopamine $\mathrm{D}_{2}$ receptor on enkephalin in this brain region [35]. Furthermore, sensitization of the locomotor response to dopamine $\mathrm{D}_{2}$ receptor agonist induced by lesion of the NAcc [5] may associate with an enhanced behavioral response to locally applied $\mu$-opioid receptor agonist [63]. Taken together with these findings, the long-lasting alterations in $\mu$-opioid receptor observed in the present study may be relevant to METH-induced changes in dopamine-dependent behavior and support the hypothesis that $\mu$-opioid receptor contributes to the expression of behavioral sensitization. This can be further supported by a parallel study from our laboratory that mice lacking $\mu$-opioid receptor expressed significantly lower intensity of behavioral sensitization induced by METH than wildtype mice (Ma et al. unpublished data), even they have been identified to possess compensatory upregulation of dopamine $D_{2}$ receptor [64] and showed enhanced locomotor response to apomorphine [64] and AMPH [65]. 
In summary, the present study has examined the effects of repeated METH treatment and abstinence on $\mu$-opioid receptors in the brain of mice. Differences found between saline- and METH-pretreated mice demonstrate that $\mu$-opioid receptors are sensitive to repeated METH treatment and alterations in $\mu$-opioid receptor are timedependently associated with the induction and expression of METH-induced behavioral sensitization. Although the contributions of $\mu$-opioid receptor to the induction or expression of behavioral sensitization induced by METH require further investigation, these findings extend and provide possible explanation for our previous study that these time-dependent alterations in $\mu$-opioid receptor might be accountable for the differential effects of NAT on the induction and expression of behavioral sensitization.

\section{Acknowledgements}

This study was supported by research funds received from the Center of Psychiatric Neuroscience at the University of Mississippi Medical Center which is supported by NIH Grant Number P20 RR017701.

\section{References}

1. Paulson P.E., Camp D.M. and Robinson T.E., Time course of transient behavioral depression and persistent behavioral sensitization in relation to regional brain monoamine concentrations during amphetamine withdrawal in rats. Psychopharmacology (Berlin) 103: 480-492, 1991.

2. Robinson T.E. and Becker J.B., Enduring changes in brain and behavior produced by chronic amphetamine administration: a review and evaluation of animal models of amphetamine psychosis. Brain Res. 396: 157-198, 1986.

3. Itzhak Y. and Ali S.F., Behavioral consequences of methamphetamine-induced neurotoxicity in mice: relevance to the psychopathology of methamphetamine addiction. Ann. N.Y. Acad. Sci. 965: 127-135, 2002.

4. Wise R.A. and Bozarth M.A., A psychomotor stimulant theory of addiction. Psychol. Rev. 94: 469-492, 1987.

5. Clarke P.B., Jakubovic A. and Fibiger H.C., Anatomical analysis of the involvement of mesolimbocortical dopamine in the locomotor stimulant actions of d-amphetamine and apomorphine. Psychopharmacology (Berlin) 96: 511-520, 1988.

6. Koob G.F., Drugs of abuse: anatomy, pharmacology and function of reward pathways. Trends Pharmacol. Sci. 13: 177-184, 1992.

7. Kalivas P.W. and Stewart J., Dopamine transmission in the initiation and expression of drug- and stress-induced sensitization of motor activity. Brain Res. Brain Res. Rev. 16: 223-244, 1991.

8. Vezina P., D1 dopamine receptor activation is necessary for the induction of sensitization by amphetamine in the ventral tegmental area. J. Neurosci. 16: 2411-2420, 1996.

9. Zhang Y., Loonam T.M., Noailles P.A. and Angulo J.A., Comparison of cocaine- and methamphetamine-evoked dopamine and glutamate overflow in somatodendritic and terminal field regions of the rat brain during acute, chronic, and early withdrawal conditions. Ann N.Y. Acad. Sci. 937: 93-120, 2001.

10. Sesack S.R. and Pickel V.M., Dual ultrastructural localization of enkephalin and tyrosine hydroxylase immunoreactivity in the rat ventral tegmental area: multiple substrates for opiate-dopamine interactions. J. Neurosci. 12: 1335-1350, 1992.

11. Chiu C.T., Ma T. and Ho I.K., Attenuation of methamphetamine-induced behavioral sensitization in mice by systemic administration of naltrexone. Brain Res. Bull. 67: 100-109, 2005.

12. Shippenberg T.S., Chefer V.I., Zapata A. and Heidbreder C.A, Modulation of the behavioral and neurochemical effects of psychostimulants by kappa-opioid receptor systems. Ann. N.Y. Acad. Sci. 937: 50-73, 2001.

13. Devine D.P., Leone P., Pocock D. and Wise R.A., Differential involvement of ventral tegmental mu, delta and kappa opioid receptors in modulation of basal mesolimbic dopamine release: in vivo microdialysis studies. J. Pharmacol. Exp. Ther. 266: 1236-1246, 1993.

14. Jones D.N. and Holtzman S.G., Interaction between opioid antagonists and amphetamine: evidence for mediation by central delta opioid receptors. J. Pharmacol. Exp. Ther. 262: 638-645, 1992.

15. Schad C.A., Justice J.B. Jr. and Holtzman S.G., Differential effects of delta- and mu-opioid receptor antagonists on the amphetamine-induced increase in extracellular dopamine in striatum and nucleus accumbens. J. Neurochem. 67: 2292-2299, 1996.

16. Spanagel R. and Weiss F., The dopamine hypothesis of reward: past and current status. Trends Neurosci. 22: 521-527, 1999.

17. Bergevin A., Girardot D., Bourque M.J. and Trudeau L.E., Presynaptic mu-opioid receptors regulate a late step of the secretory process in rat ventral tegmental area GABAergic neurons. Neuropharmacology 42: 1065-1078, 2002.

18. Johnson S.W. and North R.A., Opioids excite dopamine neurons by hyperpolarization of local interneurons. J. Neurosci. 12: 483-488, 1992.

19. Spanagel R., Herz A. and Shippenberg T.S., Opposing tonically active endogenous opioid systems modulate the mesolimbic dopaminergic pathway. Proc. Natl. Acad. Sci. USA 89: 2046-2050, 1992.

20. Olive M.F., Koenig H.N., Nannini M.A. and Hodge C.W, Stimulation of endorphin neurotransmission in the nucleus accumbens by ethanol, cocaine, and amphetamine. J. Neurosci. 21: RC184, 2001.

21. Smith A.J. and McGinty J.F., Acute amphetamine or methamphetamine alters opioid peptide mRNA expression in rat striatum. Brain Res. Mol. Brain Res. 21: 359-362, 1994.

22. Mansour A., Khachaturian H., Lewis M.E., Akil H. and Watson S.J., Anatomy of CNS opioid receptors. Trends Neurosci. 11: 308-314, 1988. 
23. Kubota Y., Ito C., Sakurai E., Sakurai E., Watanabe T. and Ohtsu H., Increased methamphetamine-induced locomotor activity and behavioral sensitization in histaminedeficient mice. J. Neurochem. 83: 837-845, 2002.

24. Badiani A., Leone P., Noel M.B. and Stewart J., Ventral tegmental area opioid mechanisms and modulation of ingestive behavior. Brain Res. 670: 264-276, 1995.

25. Nencini P. and Stewart J., Chronic systemic administration of amphetamine increases food intake to morphine, but not to $\mathrm{U} 50-488 \mathrm{H}$, microinjected into the ventral tegmental area in rats. Brain Res. 527: 254-258, 1990.

26. Yokoo H., Yamada S., Yoshida M., Tanaka T., Mizoguchi K., Emoto H., Koga C., Ishii H., Ishikawa M. and Kurasaki N., Effect of opioid peptides on dopamine release from nucleus accumbens after repeated treatment with methamphetamine. Eur. J. Pharmacol. 256: 335-338, 1994.

27. Loh H.H., Liu H.C., Cavalli A., Yang W., Chen Y.F. and Wei L.N, mu Opioid receptor knockout in mice: effects on ligand-induced analgesia and morphine lethality. Brain Res. Mol. Brain Res. 54: 321-326, 1998.

28. Burford N.T., Wang D. and Sadee W., G-protein coupling of mu-opioid receptors (OP3): elevated basal signalling activity. Biochem. J. 348(Pt 3) 531-537, 2000.

29. Wang D., Raehal K.M., Lin E.T., Lowery J.J., Kieffer B.L., Bilsky E.J. and Sadee W., Basal signaling activity of $\mathrm{mu}$ opioid receptor in mouse brain: role in narcotic dependence. J. Pharmacol. Exp. Ther. 308: 512-520, 2004.

30. Liu J.G., Ruckle M.B. and Prather P.L., Constitutively active mu-opioid receptors inhibit adenylyl cyclase activity in intact cells and activate G-proteins differently than the agonist [D-Ala2,N-MePhe4,Gly-o15]enkephalin. J. Biol. Chem. 276: 37779-37786, 2001.

31. Yoburn B.C., Billings B. and Duttaroy A., Opioid receptor regulation in mice. J. Pharmacol. Exp. Ther. 265: 314-320, 1993.

32. Vecchiola A., Collyer P., Figueroa R., Labarca R., Bustos $\mathrm{G}$ and Magendzo K., Differential regulation of mu-opioid receptor mRNA in the nucleus accumbens shell and core accompanying amphetamine behavioral sensitization. Brain Res. Mol. Brain Res. 69: 1-9, 1999.

33. Unterwald E.M., Rubenfeld J.M. and Kreek M.J., Repeated cocaine administration upregulates kappa and mu, but not delta, opioid receptors. Neuroreport 5: 1613-1616, 1994.

34. Magendzo K. and Bustos G., Expression of amphetamineinduced behavioral sensitization after short- and long-term withdrawal periods: participation of mu- and delta-opioid receptors. Neuropsychopharmacology 28: 468-477, 2003.

35. Chen J.F., Aloyo V.J. and Weiss B., Continuous treatment with the D2 dopamine receptor agonist quinpirole decreases D2 dopamine receptors, D2 dopamine receptor messenger RNA and proenkephalin messenger RNA, and increases $\mathrm{mu}$ opioid receptors in mouse striatum. Neuroscience 54: 669-680, 1993.

36. Chen J.F., Aloyo V.J., Qin Z.H. and Weiss B., Irreversible blockade of D2 dopamine receptors by fluphenazine-Nmustard increases D2 dopamine receptor mRNA and proenkephalin mRNA and decreases D1 dopamine receptor mRNA and mu and delta opioid receptors in rat striatum. Neurochem. Int. 25: 355-366, 1994.

37. Ishihara T., Akiyama K., Kashihara K., Ujike H., Hamamura T., Okada S. and Kuroda S., Activator protein-1 binding activities in discrete regions of rat brain after acute and chronic administration of methamphetamine. J. Neurochem. 67: 708-716, 1996.
38. Turgeon S.M., Pollack A.E. and Fink J.S., Enhanced CREB phosphorylation and changes in c-Fos and FRA expression in striatum accompany amphetamine sensitization. Brain Res. 749: 120-126, 1997.

39. Law P.Y. and Loh H.H., Regulation of opioid receptor activities. J. Pharmacol. Exp. Ther. 289: 607-624, 1999.

40. Deng X. and Cadet J.L., Methamphetamine administration causes overexpression of nNOS in the mouse striatum. Brain Res. 851: 254-257, 1999.

41. Itzhak Y., Martin J.L. and Ali S.F., Comparison between the role of the neuronal and inducible nitric oxide synthase in methamphetamine-induced neurotoxicity and sensitization. Ann. N.Y. Acad. Sci. 914: 104-111, 2000.

42. Heinzen E.L., Booth R.G. and Pollack G.M., Neuronal nitric oxide modulates morphine antinociceptive tolerance by enhancing constitutive activity of the mu-opioid receptor. Biochem. Pharmacol. 69: 679-688, 2005.

43. Hemish J., Nakaya N., Mittal V. and Enikolopov G., Nitric oxide activates diverse signaling pathways to regulate gene expression. J. Biol. Chem. 278: 42321-42329, 2003.

44. Torrecilla M., Pineda J. and Ugedo L., NO synthase inhibitors reduce opioid desensitization in rat locus coeruleus neurons in vitro. Neuroreport 12: 1601-1604, 2001.

45. Aley K.O. and Levine J.D., Dissociation of tolerance and dependence for opioid peripheral antinociception in rats. J. Neurosci. 17: 3907-3912, 1997.

46. Pak Y., Kouvelas A., Scheideler M.A., Rasmussen J., O'Dowd B.F. and George S.R., Agonist-induced functional desensitization of the mu-opioid receptor is mediated by loss of membrane receptors rather than uncoupling from $G$ protein. Mol. Pharmacol. 50: 1214-1222, 1996.

47. Liu J.G. and Prather P.L., Chronic exposure to mu-opioid agonists produces constitutive activation of mu-opioid receptors in direct proportion to the efficacy of the agonist used for pretreatment. Mol. Pharmacol. 60: 53-62, 2001.

48. Cai G., Gurdal H., Smith C., Wang H.Y. and Friedman E., Inverse agonist properties of dopaminergic antagonists at the $\mathrm{D}(1 \mathrm{~A})$ dopamine receptor: uncoupling of the $\mathrm{D}(1 \mathrm{~A})$ dopamine receptor from $\mathrm{G}(\mathrm{s})$ protein. Mol. Pharmacol. 56: 989-996, 1999.

49. Nilsson C.L., Ekman A., Hellstrand M. and Eriksson E., Inverse agonism at dopamine D2 receptors. Haloperidolinduced prolactin release from $\mathrm{GH} 4 \mathrm{C} 1$ cells transfected with the human D2 receptor is antagonized by $\mathrm{R}(-)-n$ propylnorapomorphine, raclopride, and phenoxybenzamine. Neuropsychopharmacology 15: 53-61, 1996.

50. Brillet K., Kieffer B.L. and Massotte D., Enhanced spontaneous activity of the mu opioid receptor by cysteine mutations:characterization of a tool for inverse agonist screening. BMC Pharmacol. 3: 14, 2003.

51. Leff P., The two-state model of receptor activation. Trends Pharmacol. Sci. 16: 89-97, 1995.

52. Vanderschuren L.J., De Vries T.J., Wardeh G., Hogenboom F.A and Schoffelmeer A.N., A single exposure to morphine induces long-lasting behavioural and neurochemical sensitization in rats. Eur. J. Neurosci. 14: 1533-1538, 2001.

53. Vezina P. and Stewart J., Amphetamine administered to the ventral tegmental area but not to the nucleus accumbens sensitizes rats to systemic morphine: lack of conditioned effects. Brain Res. 516: 99-106, 1990.

54. Vigano D., Rubino T., Di Chiara G., Ascari I., Massi P. and Parolaro D., Mu opioid receptor signaling in morphine sensitization. Neuroscience 117: 921-929, 2003. 
55. Kalivas P.W. and Duffy P., Effect of acute and daily neurotensin and enkephalin treatments on extracellular dopamine in the nucleus accumbens. J. Neurosci. 10: 29402949, 1990.

56. Vezina P., Kalivas P.W. and Stewart J., Sensitization occurs to the locomotor effects of morphine and the specific $\mathrm{mu}$ opioid receptor agonist, DAGO, administered repeatedly to the ventral tegmental area but not to the nucleus accumbens. Brain Res. 417: 51-58, 1987.

57. Chen J.C., Liang K.W. and Huang E.Y., Differential effects of endomorphin-1 and -2 on amphetamine sensitization: neurochemical and behavioral aspects. Synapse 39: 239248, 2001.

58. Levy A.D., Kim J.J. and Ellison G.D., Chronic amphetamine alters D-2 but not D-1 agonist-induced behavioral responses in rats. Life Sci. 43: 1207-1213, 1988.

59. Ujike H., Akiyama K. and Otsuki S., D-2 but not D-1 dopamine agonists produce augmented behavioral response in rats after subchronic treatment with methamphetamine or cocaine. Psychopharmacology (Berlin) 102: 459-464, 1990.

60. Cook C.D. and Beardsley P.M., The modulatory actions of dopamine D2/3 agonists and antagonists on the locomotoractivating effects of morphine and caffeine in mice. Pharmacol. Biochem. Behav. 75: 363-371, 2003.
61. Mori T., Baba J., Ichimaru Y. and Suzuki T., Effects of rolipram, a selective inhibitor of phosphodiesterase 4 , on hyperlocomotion induced by several abused drugs in mice. Jpn. J. Pharmacol. 83: 113-118, 2000.

62. Nikulina E.M., Covington H.E. III, Ganschow L., Hammer R.P. Jr. and Miczek K.A., Long-term behavioral and neuronal cross-sensitization to amphetamine induced by repeated brief social defeat stress: Fos in the ventral tegmental area and amygdala. Neuroscience 123: 857-865, 2004.

63. Churchill L. and Kalivas P.W., Dopamine depletion produces augmented behavioral responses to a mu-, but not a delta-opioid receptor agonist in the nucleus accumbens: lack of a role for receptor upregulation. Synapse 11: $47-57,1992$.

64. Tien L.T., Park Y., Fan L.W., Ma T., Loh H.H. and Ho I.K, Increased dopamine D2 receptor binding and enhanced apomorphine-induced locomotor activity in mu-opioid receptor knockout mice. Brain Res. Bull. 61: 109-115, 2003.

65. Kas M.J., van den Bos R., Baars A.M., Lubbers M., Lesscher H.M., Hillebrand J.J., Schuller A.G., Pintar J.E. and Spruijt B.M., Mu-opioid receptor knockout mice show diminished food-anticipatory activity. Eur. J. Neurosci. 20: 1624-1632, 2004. 